\title{
FELVETÉSEK A BUDAPESTI TÖRTÉNETI GYÁRÉPÜLETEK HOMLOKZATI KIALAKÍTÁSÁVAL KAPCSOLATBAN
}

\author{
MARTIN PILSITZ \\ PhD-doktorjelölt. BME, Építésztörténeti és Mủemléki Tanszék. 1111 Budapest, Mủegyetem rkp. 3. K II. 82. \\ Tel.: (+36-20) 454-8261. E-mail: pilsitz.martin@gmail.com
}

\begin{abstract}
Míg a történeti gyárépületek alaprajzi kialakítása és az egyes épületek telephelyen belüli elhelyezése alapvetően a célszerüség elvét követte, az építmények homlokzati megoldásai számos esetben ettől eltérően kerültek kialakításra, amivel kapcsolatban már eddig is számos elmélet és értelmezés született. A budapesti történeti gyárépületek példáján keresztül vázolom fel, hogy milyen - a müszaki szükségszerüségen túlmutató - tényezők befolyásolták a történeti gyárépületek külső kialakítását. Az adott építési helyszínek építészeti sajátosságai mellett ezek közé a tényezők közé sorolom a korszakban megrendezett ipari kiálításokat is, amelyek véleményem szerint a fokozottan reprezentatív megjelenés iránti növekvő igény felkeltésével komoly befolyással bírtak a történeti gyárépületek külső kialakítására. A Feszl Frigyes életművének fontos részét képező, 1860-ban épült kőbányai Dreher Sörfözde homlokzatát is elemzem. Fontos szempontként vizsgálom, hogy miként gyakoroltak befolyást a 19. században megjelenő és egyre népszerübbé váló ipari kiállítások a korabeli budapesti gyárépületek homlokzati kialakítására. A Zwack Likőrgyár építészeti fejlődéstörténetének vizsgálata keretében kitérek a korszak történeti gyárépületeinek városi térben megjelenő homlokzatai és a környező köztér között feszülő kölcsönhatás izgalmas szempontjaira is. Egyúttal újabb szemponttal bővítem azoknak a feltételeknek a körét, amelyek teljesülése esetén a történeti ipari épületek homlokzatai napjainkban müemléknek tekinthetők.
\end{abstract}

Kulcsszavak: történeti ipari építészet, Zwack Likőrgyár, Feszl Frigyes, Dreher Sörfözde, Első Magyar Csavargyár, múemlék, ipari örökség

\section{A TÖRTÉNETI GYÁRÉPÜLETEK ALAPRAJZI KIALAKÍTÁSA ÉS AZ EGYES ÉPÜLETEK TELEPHELYEN BELÜLI ELHELYEZÉSE}

A 19. században a gyárépületek alaprajzi kialakítása során a gyakorlati szükségszerüségeket, például a specifikus gyártási eljárást vagy a gépek méreteit tekintették meghatározó szempontoknak. A 19. század végén ezek mellett már a ,gazdasági üzemeltetési szempontok" (Friedrich W. Taylor, 1856-1915) is kezdtek befolyást gyakorolni az alaprajzi kialakításra, és ezek léptek az alaprajz és a térkialakítás szervezésében az addig alkalmazott tapasztalati értékek helyére. ${ }^{1}$ Az ezek eredményeként kialakuló racionalizációs módszereknek a gyakorlatba való átültetése már a gyártóépületek és müszaki berendezések módosítását is szükségessé tette. A gyártási

\footnotetext{
${ }^{1}$ Taylor 1911.
} 
folyamatot úgy alakították ki, hogy a gyártás az üzemen belül lehetőleg egyetlen irányba haladjon. A gyárépületek alaprajzát a gyártás menetének megfelelően úgy tervezték, hogy a szállítási utak is a lehető legrövidebbek legyenek. Az optimalizált térelrendezés előretörése többek között az olyan funkcionalitást szolgáló építészeti elemek alkalmazásában is megmutatkozott, mint a többszintes gyárépületeket összekötő ipari épülethidak. ${ }^{2}$ Ipari épülethidat alkalmazó iparágak gyárlétesítményei közül a Budapesten/Kőbányán található Fővárosi Serfözde Rt. épületeit (1912), és az 1905ben Detroitban (USA-ban) épült Packard Factory No. 10 autógyár épületét emelném $\mathrm{ki}^{3}{ }^{3}$ Ezek mellett a gyárak jellegzetes elemévé váltak a gyártócsarnokok épülettömegének ellenpontját alkotó, egyenesen a magasba törő és messziről is jól látható ipari kémények. Az igényesen tervezett kémények méretéből egyrészt a tüzelöberendezés teljesítménye is leolvasható volt, vagyis átvitt értelemben magára a gyár összteljesítőképességére is következtetni lehetetett. Másrészt a kémény müszaki építőelemként a kazán- és gépházak elhelyezkedését is jelezte.

A történeti gyárépületek alaprajzának kialakítási elveit vizsgálva számos - a tervezési és építési szakasz különböző szintjein érvényesülő - célszerüséget szolgáló tényező fedezhető fel. Megállapítható továbbá, hogy az emberi tényező és az emberi szükségletek a tervezési szempontok sorában viszonylag alárendelt szerepet játszottak, ami az egyik oka lehet annak, hogy ez az épülettípus mindmáig különleges megítélés alá esik az építészeten belül. A történeti gyárak telephelyen belüli elrendezése a célszerüség logikáját követte, de ez a különböző iparágakon belül eltérő koncepcionális alapokon történt. A kőbányai sörfőzdék építészeti fejlődése során az üzemtelepeken zajló több évtizedes építkezési és átépítési tevékenység következtében olyan összetett szerkezetủ beépítettség alakult ki, mely komplexitásában szinte már urbánus struktúrákra emlékeztet. A város peremén létesített telephelyek a térségben megfigyelhető alacsony telekárak miatt megfelelő méretekkel és területtartalékokkal rendelkeztek, ezért még inkább elősegítették a komplexitás irányába történő elmozdulást. ${ }^{4}$ Ráadásul a telkek topográfiai adottságai is kedvezőek voltak, hiszen nem ágyazódtak bele szorosan a város szövetébe így szomszédos beépítés hiányában az épületek az üzemi telephelyen belül funkcionális szempontok szerint szabadon elhelyezhetők voltak. Az itt letelepedő sörfőzdék számára a kőbányai pincerendszer további helyszíni előnyt biztosított, hiszen további dimenzióval bővítette a rendelkezésre álló funkcionális lehetőségeket. A Kőbányán kínálkozó kedvező keretfeltételek miatt a területen 1870 és 1915 között összesen 6 ipari szerkezetű nagysörfözdét alapítottak, melyek együttesen Európa legnagyobb monosörfözde ipari területét al-

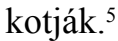

Ezzel szemben a Duna mentén, a Soroksári és a Külső Váci úton letelepedő gépgyárak telephelyeinek beépítési szempontjai között jóval inkább az adott cég fejlödéstörténete tekinthető döntő tényezőnek. A Budapesten alapított gépgyártó üzemek

\footnotetext{
${ }^{2}$ Salviatmosaics 2015.

${ }^{3}$ Packard 2011.

${ }^{4}$ Dausz 1913.

${ }^{5}$ Pilsitz 2012a.
} 
nemritkán fémfeldolgozó iparosok kisebb mühelyeiből fejlődtek ki, melyekben a cégalapító még maga is közremüködött, majd hosszabb időn keresztül magántőkéje folyamatos befektetésével szakaszosan bővítette tovább üzemét és épületeit. Ez az üzemfejlesztési mód világosan leolvasható a telephelyeken létesített új épületek, hozzáépítések és bővítmények additív építészeti struktúrájáról. A budapesti üzemek példáján keresztül az is igazolható, hogy a belvárosból a peremkerületekbe kezdődő elvándorlást elsősorban az üzemek fokozatos bővítési igénye váltotta ki. Jó példa erre a gyártípusra az Erste Ungarische Maschinenbaufabrik a Külső Váci úton (1869) és Pick Ede Külső Váci út 40. sz. alatti gépgyára (1890). Mindkét cég épületeit inkább kisebbnek nevezhetjük a korszakban alapított üzemtelepekhez képest. Telephelyeik és az épületeik kialakítása azonban mégis arra enged következtetni, hogy ezeket a létesítményeket már teljes egészében a fémfeldolgozó üzemek funkcionális igényrendszere alapján tervezték, így tipikusnak tekinthetők (1. ábra).

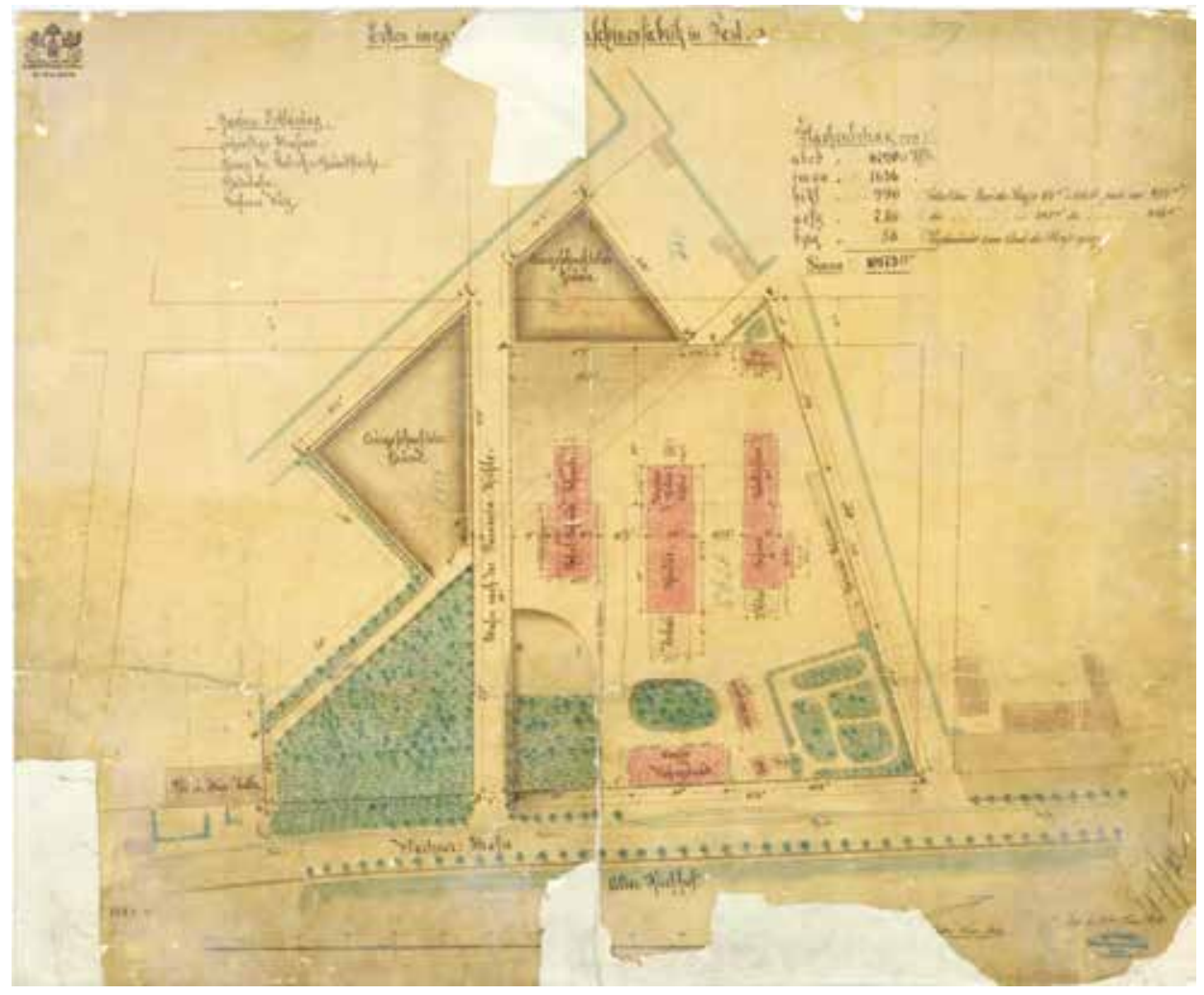

1. ábra. Erste Ungarische Maschinenbaufabrik. Váci út, 1869 (Forrás: Budapest Főváros Levéltára XV.16.b.224.034) 


\section{A BUDAPESTI TÖRTÉNETI GYÁRÉPÍTMÉNYEK HOMLOKZATI KIALAKÍTÁSÁNAK TÉNYEZÖI}

Míg a történeti gyárépületek alaprajzi kialakítása, és az egyes épületek telephelyen belüli elhelyezése alapvetően a célszerüség elvét követte, az építmények homlokzati megoldásai számos esetben ettől eltérően kerültek kialakításra, amivel kapcsolatban már eddig is számos elmélet és értelmezés született. Ezzel kapcsolatban utalni kívánok Günther Bandmann építészettörténész épülethomlokzatok ikonológiájával foglalkozó Ikonologie der Architektur címü müvére. ${ }^{6}$ A történeti gyárak homlokzati kialakításának indoklása jórészt arra a tényre hivatkozik, hogy ezek nagy része a historizmus korszakában keletkezett. Ez az érvelés ugyan nem tekinthetö hibásnak, mégsem szolgál teljes körü magyarázattal az ezen a területen tapasztalható ellentmondásokra. A történeti ipari épületek tervezésekor a fokozottabb mechanikai behatások és szennyeződések veszélye miatt a gyár homlokzatával szemben támasztott technikai elvárások alapvető tényezőnek számítottak a külső héj megtervezésekor. Ezzel egyidejüleg azonban a gyárak és teljes ipari létesítmények külső megjelenését egyre inkább az „újszerü” technikai építészeti elemek, mint pl. a nagyméretü szellőzőelemek, a csővezetékek és a magas ipari kémények kezdték meghatározni. A technikai szempontokon kívül azonban ekkor már számos más fontos tényező is kezdett hatást gyakorolni a homlokzati kialakításra, mint például az építési helyszín regionális építészeti sajátosságainak figyelembevétele, a korszakban egyre népszerübbé váló és a nagyközönséget is élénken foglalkoztató ipari kiállítások, valamint az ipari épületek reprezentációs szerepe. Ezeket a tényezőket a továbbiakban néhány budapesti gyár példáján keresztül mutatom be.

\section{REGIONÁLIS ÉPÍTÉSZETI SAJÁTOSSÁGOK FIGYELEMBEVÉTELÉVEL TERVEZETT GYÁRHOMLOKZAT: DREHER SÖRFÖZDE, FESZL FRIGYES, BUDAPEST/KÖBÁNYA (1865)}

Az épület müszaki rendeltetése első pillantásra félreérthetetlenül egyértelmü a szemlélő számára. A homlokzatot a falazott felületek dominálják, míg az épület konstruktív-funkcionális jellegét technikai rendeltetésü építőelemek, mint pl. a szellőztetők, az ipari kémény és az aszaló nagyméretű kiszellőztető kürtője érzékeltetik. A kiugró és lépcsőzetes elrendezésü épülettömegek révén az objektum világosan elkülöníthető részegységekre tagolódik. Az egyes épületrészeken belül a térfunkciók homlokzatra vetítése, már-már kívülről leolvashatóvá tétele egyedi méretezésü ablakok elhelyezésével valósul meg. Itt megfordul a korábban elfogadott tervezési irány, hiszen ez esetben az épület belülröl kifelé történő tervezéséről beszélhetünk. Ez az elv a sörfözde homlokzatát szinte projekciós felületté alakítja, és egyben az épület történetének jelentős részét is leolvashatóvá teszi. A belvárosi (Mayerffy és Petz) 
sörfőzdékkel ellentétben, melyek építészeti kialakításukkal, magassági kiképzésükkel és arányaikkal még a környező városi kötőszövetnek alárendelten létesültek, így nem vállalták fel az épület funkciói és a külvilág közötti közvetítői szerepet, a Dreher Sörfőzde esetén ellentétes koncepció figyelhető meg. A külső homlokzat sarkain lizénaszerü falsávok húzódnak, melyek elhelyezését statikai okok nem indokolják, vagyis csupán függőleges tagoló elemként szolgálnak, és a magasba törő kéményekkel a komplexum vízszintesen elterülő épülettestének világos ellenpontjaként szolgálnak. A müszaki építményelemek is díszítményekkel készültek, ezért itt is a homlokzat esztétikai felértékeléséről beszélhetünk. A lépcsőzetesség elve a tetőkialakításnál is megfigyelhető. Az egyes épületrészek saját nyeregtetőket kaptak, amelyek gerincmagasságban egymással szembefordítottan helyezkedtek el. Ezzel az egyes funkciókat befogadó területek további individualizálása figyelhető meg, és a függöleges irányú gyártási folyamat is még inkább megjelenítődik kifelé. Az épület 1,00 méter magas lábazaton nyugszik, mely a lizénákkal a létesítménynek nyugodt, megbízható alapokon nyugvó, már-már védett jelleget kölcsönöz, így az épület, vagyis a benne müködő vállalat, kifelé a megbízhatóság szemantikus üzenetét közvetíti (2. ábra).

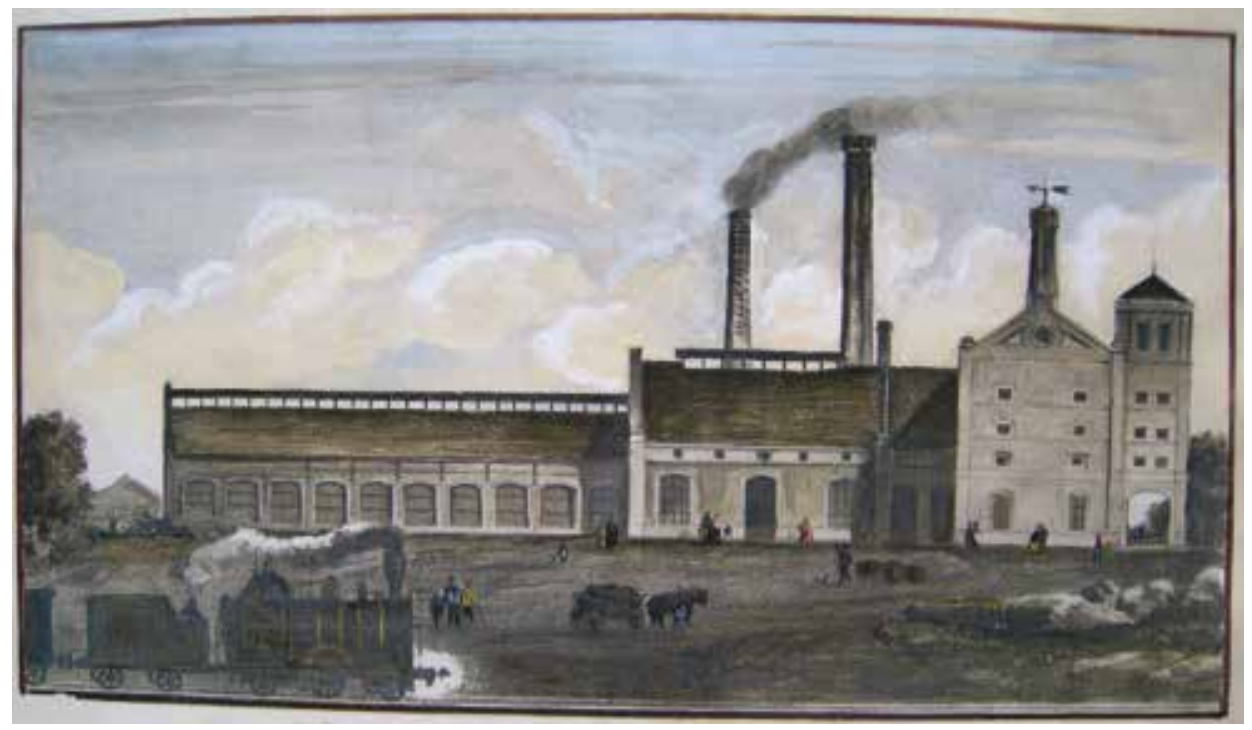

2. ábra. Dreher Sörfözde. Köbánya, 1865

(Forrás: Budapest Főváros Levéltára XV.17.b.szb.19667b)

Az épület tervezését Anton Diescher építőmesterre bízták, a homlokzat terveinek elkészítésével azonban Feszl Frigyes építészt bízták meg. A sörfözde terveit az önálló magyar nemzeti formanyelv kialakítására törekvő Feszl nagyjából a Pesti Vigadó (1859-1865) tervezésével egy időben készítette el. Az 1848-as polgári forradalom 
bukását követő időszakban a szubjektív nemzeti romantikát tükröző formanyelv a nemzeti érzület erősítését és a nemzet identifikációjának támogatását szolgáló legitim reakciónak tekinthető. Németországban például a romantika - mint a nemzeti identitás keresésének manifesztációja és a középkor jelentőségének újrafelfedezése - nélkül nem kerülhetett volna sor több befejezetlen dóm, pl. a kölni dóm, mint a nemzeti reprezentáció megnyilvánulását közvetítő építmény befejezésére. A korai gyárépületek erre a korszakban megfigyelhető törekvésre kínálnak építészeti önkifejezési lehetőséget, hiszen a vállalatalapítások túlnyomó része polgári kezdeményezésen alapult, és a polgárság tevékenysége az 1848-as forradalmakat követő időszakban a korábbi politikai színtérről egyre inkább a vállalkozási területre helyeződött át. A Feszl által alkalmazott stilisztikai eszközökről Komárik Dénes így fogalmaz: „Romantikus architektúrájában három vonulatot figyelhetünk meg, a gótizáló, a keleties formálású »Rundbogenstil« és a magyaros formaszándékú alakitásét."

Feszl tehát a kor romantikus építészete jegyében némi esztétikai „túlkapásokkal” teszi épületeit igazán egyénivé. A sörfőzdeépületek homlokzatának esztétikai kialakítása terén Feszl számára viszonylag korlátozott mozgástér áll rendelkezésre, így a Dreher Sörfözde formavilága összességében tárgyilagos marad, sőt a Pesti Vigadó épületével összevetve kimondottan gazdaságos kialakításúnak tekinthető. A sörfőzdeépület célja nem teszi lehetővé a homlokzat plasztikus értelemben vett díszítését, így Feszl a felület „,vetítővászonszerü” kialakítására szorítkozik. Jellemző adalék, hogy egy fennmaradt ábrázoláson Feszl a sörfözde komplexumot a korban tipikus módon romantikusan, harmonikusan a tájba illesztetten mutatta be. Az épület elött még egy éppen elhaladó mozdonyt is ráfestetett a képre, mely a valóságban ilyen formában soha nem létezett, vagyis minden bizonnyal a reményteli jövő elővetítését szolgálta. Ezzel az idealizált ábrázolással Feszl romantikusan szenvedélyes hangulatot teremtett, amellyel saját értékrendjét vetítette át a gyárépítészetre. A Dreher Sörfőzde homlokzata ebből a megközelítésből is fontos szerepet képvisel Feszl életmüvében. A többi meglévő kőbányai sörfözdeépülettel ellentétben (pl. Carl Rohrbacher Sörfözdéje, 1845) ennek ellenére itt már nem beszélhetünk pusztán olyan látványhomlokzatról, mely historizáló kialakításának egyetlen célja a sörre, mint hagyományban gazdag italra való hivatkozás megteremtése lett volna. A Dreher Sörfőzde homlokzatát ugyanis a funkcionalitás által diktált elemek dominálják, melyek Feszl tervezői munkája hozzáadott értéke révén esztétikailag felértékelődnek. A technikai szempontból szükséges univerzális elemek és Feszl ezek külső megjelenésére gyakorolt individualizáló befolyása sajátos kombinációhoz vezetett, amelynek eredményeként regionális hivatkozásokat tartalmazó hiteles gyárhomlokzat jött létre. Helyi és általános építészettörténeti jelentősége ellenére az épületet az 1990-es években lebontották. ${ }^{8}$

\footnotetext{
${ }^{7}$ Dénes 1993.

${ }^{8}$ Váczi 2001.
} 


\section{AZ IPARKIÁLLÍTÁSOK ÉS A GYÁRÉPÍTÉSZET KÖZÖTTI KÖLCSÖNHATÁS}

A 19. századi iparosodás előrehaladtával a nagyközönség is egyre nagyobb érdeklődéssel fordult a müszaki újdonságok felé. Ezért a cégek is keresni kezdték a lehetőséget termékeik széles nyilvánosság előtti bemutatására. Szinte minden iparág saját szakfolyóiratot alapított, sőt a napilapokban is rendszeresen jelentek meg a gyárépületekről és cégalapításokról szóló értekezések (lásd Vasárnapi Újság). A technikai újdonságok bemutatására ekkor kezdtek el nyilvános rendezvényeket is tartani, melyek keretében a nagyközönség is tudomást szerezhetett a legújabb felfedezésekröl. 1842-ben Pesten megtartották a négyhetes Első Magyar Iparmü Kiállítást, mely a hatalmas sikerre való tekintettel a következő években is rendszeresen megtartásra került. ${ }^{9}$ Az egyik legjelentősebb ilyen rendezvény az 1885-ben a budapesti Városligetben tartott Országos Általános Kiállítás volt. ${ }^{10}$ Kiállítási helyszínként $14000 \mathrm{~m}^{2}$ alapterületü, ún. iparcsarnokot létesítettek (építész: Keresztély Ulrich), melynek leírása igényes építészeti kialakításról tanúskodik: „„Épszögény“ (téglány) alaprajzú, 4 sarkán egy-egy pavilon, a pavilonok között egy-egy összesen 4 császár-kori motívumokkal díszitett diadalkapu emelkedett. A 22 m magasságú kapuk és sarokpavilonok tégla és köanyagból, az összekötő szárnyak vas-üveg szerkezetekböl épültek. A két középső egymást keresztezö csarnok metszéspontjában a nyolcszögü tambur fölött 48 és fél m magas a kupola, az épületnek »tiszta, új-reneszánsz styl « jelleget adva.” Az 1896-ban tartott budapesti „Ezredéves Kiállítás” nem tekinthető ugyan tisztán ipari kiállításnak, de $520000 \mathrm{~m}^{2}$-es alapterülete jól mutatja a hasonló rendezvények népszerüségét és presztízsét, amely a résztvevő cégek számára a nagyközönség irányában korszerủ reprezentációs eszköznek számított. Az 1896-os kiállítási területet túlnyomórészt tengelyszimmetrikusan szervezték, és 234 különböző méretủ épületnek adott helyet. A Nicholson gépgyár millenniumi kiállításra készített kiállítási standja jól mutatja a cégek jelentős reprezentációs igényét. ${ }^{11}$ A rendezvény az 1764-es Londoni Iparkiállítás és az 1798-as Párizsi Iparkiállítás mintájára került megszervezésre, amelyet több más berlini és bécsi kiállítás is követett. Ezekből az iparkiállításokból fejlődtek ki végül a későbbi világkiállítások (Párizs 1867, Bécs 1873, Párizs 1889 és 1900, Chicago 1893). ${ }^{12}$

Az iparkiállításokkal olyan helyszín alakult ki, ahol a cégek bemutathatták magukat, és teljesítőképességük közvetlen összehasonlítására is alkalmuk nyílt. A nagyobb cégek saját pavilonokban mutatkoztak be, a kisebb cégek pedig közös pavilonokon osztoztak. Ezekkel az általában egyszintes és gyakran szabadon álló épülettestekkel a kiállítások funkcionálisan és térben is több kisebb külön kiállításra tagolódtak. ${ }^{13} \mathrm{Az}$ 1907-ben tartott Pécsi Országos Kiállítás és Vásár építészeti kialakításával kapcsolatban Horváth Csilla a következőket jegyzi meg: „, A tervezö bizott-

\footnotetext{
${ }^{9}$ Nyárády 1962.

${ }^{10}$ Prakfalvi 2001.

${ }^{11}$ Bencze 2006. 88.

${ }^{12}$ Bálint 1897.

${ }^{13}$ Császár 1996.
} 
ság felügyelte, hogy a pavilonok egységes stílusban készüljenek el. ... Az elképzelés szerint a kor divatos, magyaros, szecessziós stílusában kellett megtervezni az épületeket. Másik szempont volt, hogy a külsö megjelenés is utaljon a benne kiállitott anyagokra." ${ }^{14}$ A közvetlen összehasonlíthatóság miatt így a versenytársak általi nyomás is többszörösére növekedett, ezért a cégek igyekeztek kiemelkedni a konkurencia soraiból, és terméküket különleges keretek között bemutatni. A kiállító pavilonok tér- és építészeti koncepciója ezért kiemelkedő jelentőségűvé vált, hiszen építészeti díszletként a kiállított termékek hatását volt hivatott erősíteni. Ennek során mai szemmel már-már enyhén színpadias kialakítások is előfordultak. A cégek hagyományokra visszatekintő múltjuk és megbízhatóságuk bizonyítására újonnan kifejlesztett termékeik mellett régi gépeket is kiállítottak. A kiállítási pavilonok a technikai újdonságok bemutató helyévé váltak. A kiállítások jelentősége összességében mégis jóval túlmutatott a tárgyak és termékek bemutatásán. ${ }^{15} \mathrm{~A}$ rendezvények területén zenepavilonokat, szökőkutakat, sétautakat és közösségi tereket is kialakítottak, melyek így a nagyközönség számára a kor társadalmi és szellemi keresztmetszetének tükörképét is alkották. ${ }^{16}$

\section{A FOTOGRÁFIA TOVÁBB BÖVÍTI A PREZENTÁCIÓS LEHETŐSÉGEK SORÁT}

A fotográfia elterjedésével a cégek prezentációs lehetőségei a korábbiak sokszorosára bővültek. ${ }^{17} \mathrm{~A}$ fotókat ekkor kezdték el alkalmazni a távoli, ezért a nagyközönség számára addig „láthatatlan” gyárlétesítmények és gyártóberendezések dokumentálására és bemutatására. ${ }^{18} \mathrm{~A}$ tér és az épületek fotográfián való megjelenítése során a valóságban háromdimenziós épülettömegek és terek kétdimenziós felületre való átvitelében rejlő új lehetőségeket hasznosították. Ez a jelentős síkbeli váltás kiváló játékteret nyújtott a szándékosan szubtilis értelmezések és szubjektív üzenetek közvetítésére is, ezért alkalmazása jóval túlment a realitás tárgyilagos bemutatásán. ${ }^{19}$ A gyártólétesítménybe ellenőrzötten engedett bepillantás célja a nagyközönségnek a cég teljesítőképességéről és megbízhatóságáról való meggyőzése volt. A gyárak a tereikbe engedett újdonságnak számító bepillantás miatt egyre inkább törekedtek gyártóhelységeik és müszaki berendezéseik reprezentatív kialakítására is. ${ }^{20}$ Ezáltal a média kezdett befolyást gyakorolni az ipari épületek építészeti kialakítására. Ez a jelenség többek között a sörfőzdék gép- és fözőházainak egyre igényesebb kialakításában is világosan megmutatkozott. Jó példa erre az Első Magyar Részvény

\footnotetext{
${ }^{14}$ Horváth 2001. 72.

${ }^{15}$ Hidvégi 2001.

${ }^{16}$ Distel 1929.

${ }^{17}$ Plank 2001. 123-130.

${ }^{18}$ Föhl 1981. 107-122.

${ }^{19}$ Borström 1989. 1614-1618.

${ }^{20}$ Pieper 1994. 104-115.
} 


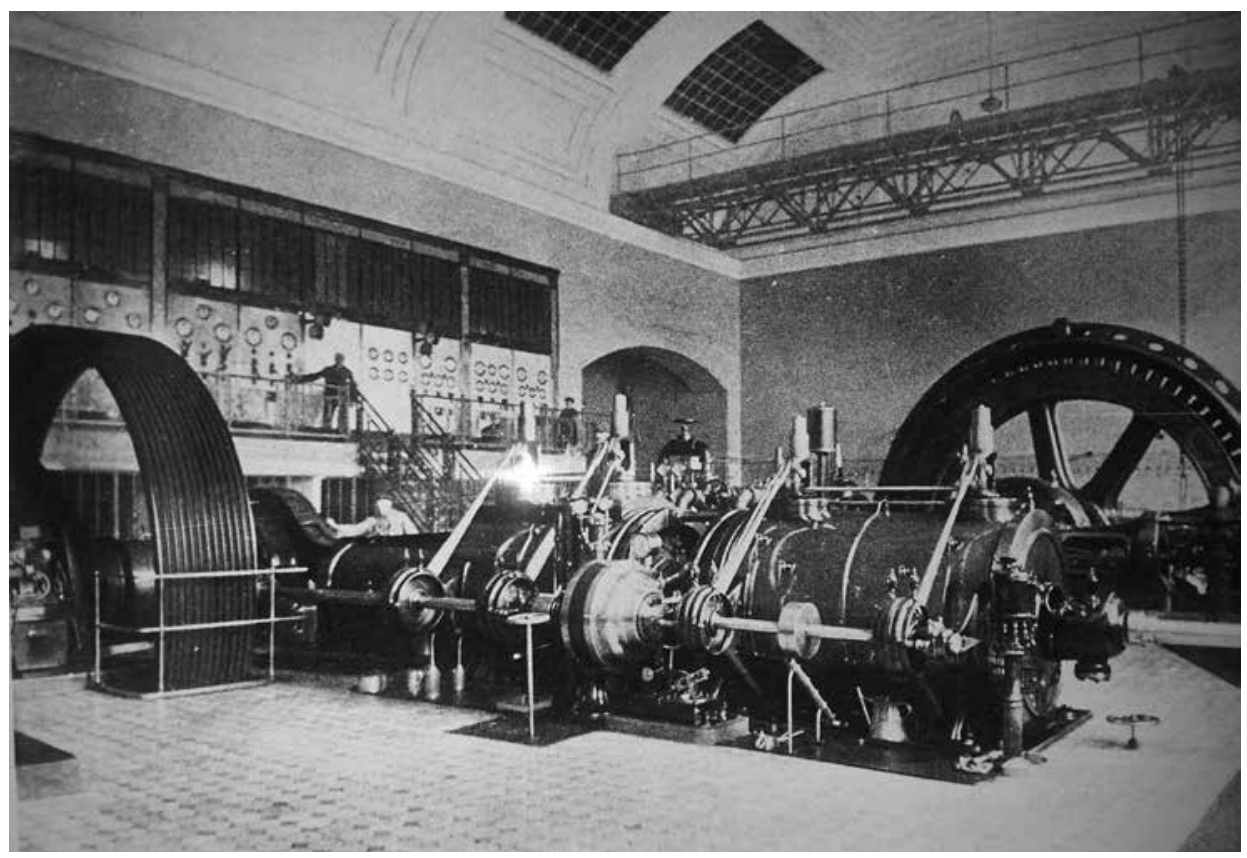

3. ábra. Első Magyar Részvény Sörfőzde Rt. gépháza. Belső tér, 1912 körül (Forrás: Dreher Sörgyárak Zrt. Múzeumának Archívuma)

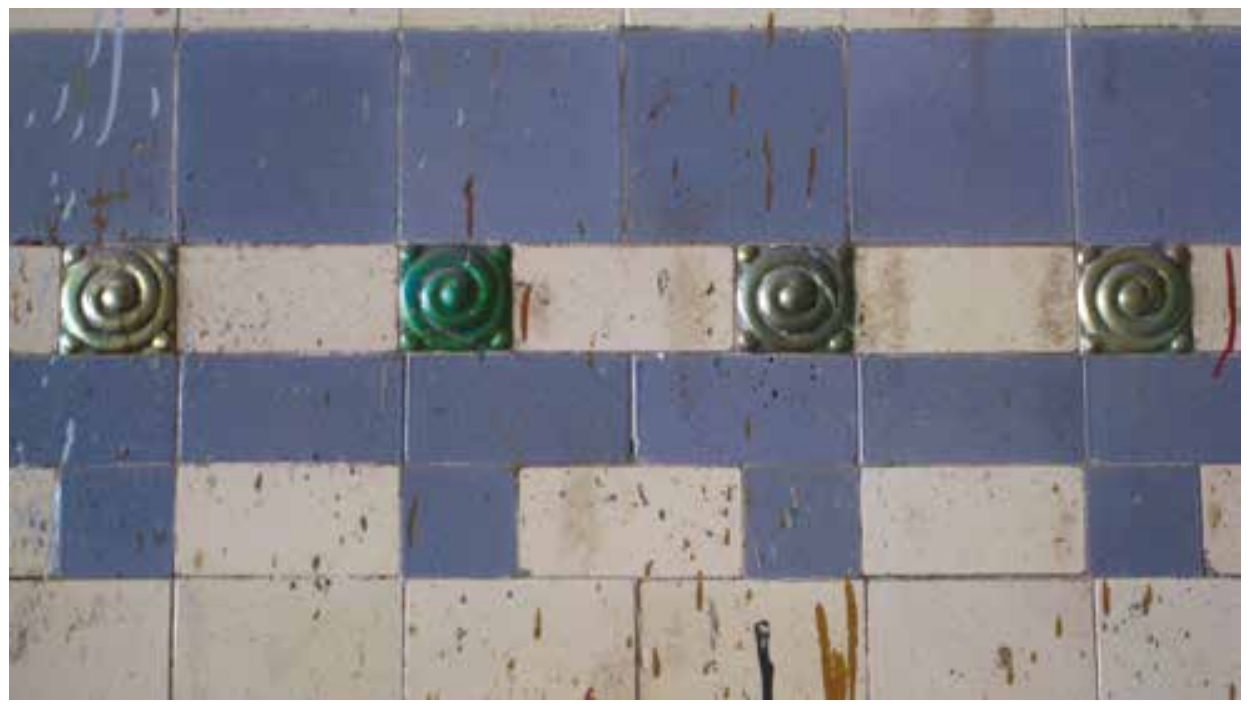

4. ábra. Első Magyar Részvény Sörfőzde Rt., jelenleg Dreher Sörfőzde, Gépház. Kerámialapos díszes falburkolat (Fotó: Martin Pilsitz) 
Sörfőzde Rt. gépháza, ahol a mủvi úton előállított energia forrását: az értékes gőzgép kialakulását mutatták be a látogatóknak. ${ }^{21} \mathrm{~A}$ belső tér kialakítása itt is jelentősen túlment a müszaki szükségszerüségen, és igényes díszítésével kimondottan reprezentációs célokat szolgált. Az igényes kerámialapos fali burkolatok, a mutatós kapcsolópultok és a fényesre polírozott gépek szinte megnemesítették az egyébként technikai célú helység hatását (3-4. ábra).

A gépházat a következő kiállításon fotográfiákon mutatták be a nagyközönségnek, mely így a kiállítás kibővített részévé vált. A szemlélők így a vállalat szándékai által irányított - nyilvánvalóan a napi élet valóságától tudatosan elrugaszkodott - módon kaptak bepillantást a gyártólétesítmény belső kialakításába.

Összefoglalóan megállapítható, hogy az iparkiállítások révén a gyárépítészettel közvetlen kölcsönhatásban fejlődő kiállításépítészet alakult ki, amely a maga sajátos módján a továbbiakban is szervesen befolyásolta a korabeli gyárépítészet fejlődését. Erre a kölcsönhatásra szolgál korai példával az F. Cendrier és A. Barrault által 1852ben tervezett Palais d'Industrie és J. Paxton Londonban 1851-ben kiállítási és rendezvénycsarnok céljára létesített Kristály Palotája. Az építmények tervein számos építészeti stílusra vonatkozó utalás fedezhető fel. A Kristály Palota esetében ráadásul már időterv alapján modulokból, tengely- és raszterelemekből összeállított építményről beszélhetünk, melynek elemeit előre gyártottan és részleteit szabványosítottan dolgozták ki. A felhasznált építőanyagok mindegyike: pl. az öntöttvas, a kovácsoltvas és az üveg is ipari terméknek számít. ${ }^{22} \mathrm{~A}$ kiállításépítészet így további lendülettel szolgált az ipari építészet számára, amely azután a cél- és ipari építészet keretein túllépve az általános építészeti kultúra fejlődésére is komoly befolyást gyakorol.

\section{AZ IPARI ÉPÜLETEK REKLÁMCÉLÚ ÁBRÁZOLÁSA}

A fotográfia és a gyárépületek közötti kölcsönhatás nagyobb folyamat részeként alakult ki, melynek során a cégek a média által nyújtott lehetőségeket saját önkifejezésük eszközeként kezdik alkalmazni. Az ábrázolásokon az ipari épületeket szimbólumokká stilizálják, amelyekkel a megbízhatóság, a minőség, a hagyományosság és a sikeresség szemantikai üzenetét jelenítik meg. ${ }^{23} \mathrm{Az}$ a tény, hogy a public relations kifejezést már 1882-ban alkalmazni kezdték a Yale Universityn (USA) jól mutatja, hogy a reklám és a szemantikai üzenet közötti összefüggés már akkoriban kutatások témáját képezte. ${ }^{24}$ Ennek a gyakorlati alkalmazását a levesfüszergyártó Julius Maggi

\footnotetext{
${ }^{21}$ Hassler-Kierdorf 2000. 15.

${ }^{22}$ Kammerer 1985. 8-11.

${ }^{23}$ A korszakra jellemző reklámhordozó volt 1890 után a zománctábla, mely időjárásálló és tartós plakátként a külső reklámhordozó szerepét töltötte be. Idővel a kereslet annyira megnőtt, hogy önálló zománcgyárakat is alapítottak (pl. a Bonyhádi Zománc Gyár, 1909), ahol ismert grafikusok és festőmüvészek ábrázolásai alapján különféle technikával (pl. litográfiával) készültek reklámtáblák.

${ }^{24}$ Merten 1999. 279.
} 
példája is jól mutatja, hiszen a cég termékei propagálására és értékesítésének támogatására már 1886-ban saját „,reklám- és sajtóirodát” hozott létre Németországban. Itt is megfigyelhető a gyártóépületek homlokzatainak reklámhordozóként történő alkalmazása, így a Maggi-cég Saint-Omer-en-Chaussée-ben (1897, Franciaország) található üzeme postai levelezőlapokon is megjelenik. ${ }^{25}$

Az ipari tömeggyártás logikus következményeként az irodai munkát is racionalizálták. Erre a célra a nagyobb üzemekben standardizált, előnyomott fejléces levélpapírt vezettek be. Az előnyomott fejlécek az üzem címe és később telefonszáma mellett gyakran az idealizált gyár igényes grafikai ábrázolását is tartalmazták. A korabeli ábrázolásokon a létesítmények gyakran élénk forgalmú utcaképpel és füstölgő gyárkéménnyel jelennek meg. Olykor még a vállalat teljesítőképességét igazolni hivatott belső megjelenítés is előfordul. Az ipari kiállításokon elnyert kitüntetésekre tett utalások is gyakoriak a termék minőségének igazolásaként. Jó példa erre a budapest-kőbányai Első Magyar Műhordógyár levélpapírja, melynek fejlécén igényes grafikai kidolgozással a következő szöveg olvasható: „,1896. MILLENNIUMI

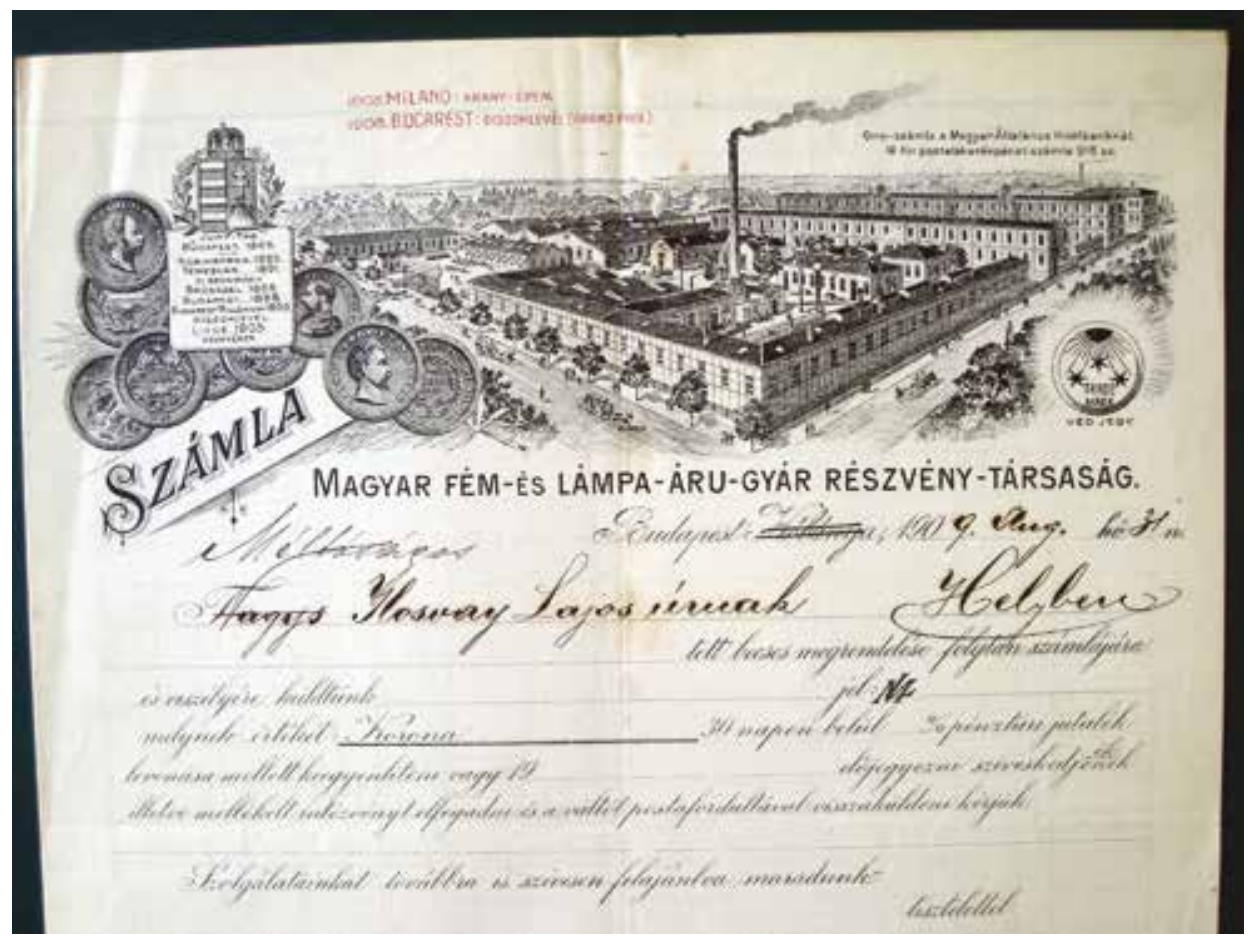

5. ábra. Számla a gyár ábrázolásával. Magyar Fém- és Lámpa-Áru-Gyár Rt., 1909 (Forrás: Szabó Ervin Könyvtár) 
KIÁLLITÁS BUDAPEST. DÍSZ-OKLEVÉL. LEGNAGYOBB KITÜNTETÉS."26 Világosan kitünik, hogy a vállalkozók az önkifejezésnek ezt a kézenfekvő eszközét egészen tudatosan alkalmazták a potenciális ügyfelek meggyőzésére ${ }^{27}$ (5. ábra).

\section{AZ IPARI ÉPÜLET MINT A VÁLLALAT, ILLETVE A VÁLLALKOZÓ REPREZENTÁCIÓS ÖNKIFEJEZÉSÉNEK HORDOZÓJA}

A történeti gyárépületek homlokzati kialakítására számos tényező volt hatással. Ide sorolhatók az adott iparágban alkalmazott specifikus gyártási eljárások és a cég építési tevékenységének kronológiája is. Ezen belül is főként az játszott szerepet, hogy lassan növekvő, vagyis additív épületállománnyal rendelkező cégről, vagy nagyberuházásként megvalósult, hatalmas dimenziójú épületekről beszélhetünk-e. A homlokzati kialakítást másrészt nagyban meghatározta az építési koncepció (csarnok, egy- vagy többszintes épület), az alkalmazott épületszerkezet és a felhasznált építőanyagok is. Döntő szerepet játszott a helyválasztás (belvárosi vagy a város perifériáján elhelyezkedő) is. A cégek reprezentációs és önkifejezési igénye szintén jelentős befolyásoló tényezőnek számított.

Az ipari épületek homlokzati kialakítása és a köztér közötti kölcsönhatást, valamint a gyár utcai térben való elhelyezésének változatait mutatom be a továbbiakban a Zwack Likőrgyár és az Első Magyar Csavargyár épületeinek példáján keresztül. Az itt látható kialakításnak több alváltozata is megfigyelhető.

\section{FELÜLETCENTRIKUS ÉPÍTÉSZETI KONCEPCIÓ AZ IPARI ÉPÜLETEK HOMLOKZATI KIALAKÍTÁSA ÉS A KÖZTÉR KÖZÖTTI KAPCSOLATRENDSZERBEN}

1894-ben a Zwack élvezeti cikkeket gyártó cég új likőrgyárat építtetett a Soroksári úton (az épület jelenleg a 29-es szám alatt található). A helyszínválasztás mögött nyilvánvaló stratégiai megfontolások húzódtak meg, hiszen az üzemtelep a Soroksári út központhoz közel fekvő szakaszán, a Concordia malom közvetlen közelében található. A Zwack-üzem így kezdettől fogva iparvágány csatlakozással rendelkezett. A Soroksári út a Dunával párhuzamos fekvése miatt a föváros egyik fö ellátási útvonalát alkotta. A századforduló idején a Soroksári út mentén letelepedett gyártóüzemek sürüsége alapján az útvonalat a város egyik legjelentősebb belterületi ipari fejlödési tengelyének is nevezhetjük, amely ennek megfelelően komoly áru- és személyforgalmat bonyolított le. Vagyis a Zwack Likőrgyár telephelye kezdettől fogva exponált helyen helyezkedett el.

\footnotetext{
${ }^{26}$ Forrás: Szabó Ervin Könyvtár.

${ }^{27}$ Buechersammler 2015.
} 
A telephely alaprajzi kialakítása belső udvar köré szervezett blokkperemes beépítést mutat. Az üzem megközelítése közvetlenül az utcáról történt, vagyis tudatosan eltekintettek a köztér és az építmény közötti átmeneti jellegü terület kialakításáról. Ez a típusú térkapcsolódás erős kölcsönhatást eredményezett az épület és a Soroksári úton elhaladó forgalom között. A föhomlokzat a Soroksári útra néz, így adottságai révén a tervező tudatos döntése következtében ez a reprezentációs célú homlokzatszakasz a héjfunkciónál jóval magasabb jelentőségtartalmú üzenet hordozójává válik. Ennek érdekében a tervező számos további építészeti eszközt is alkalmazott, ide tartoznak az oldalsó és középrizalitok, a tengelyszimmetrikus kialakítás, a központi bejárat építészeti eszközökkel történő hangsúlyozása és a masszív cégtábla elhelyezése is. A homlokzat hatását tovább fokozzák az igényesen kialakított klinkertégla falazatú felületek és a színválasztás is. Megállapítható, hogy a homlokzati kialakítás kiemelt célja az épületnek a korszak értelmezése szerinti újszerü társadalmi méltósággal való felruházása oly módon, hogy az épület ipari rendeltetése se kerüljön háttérbe. Az itt felvázolt reprezentatív formaválasztás nyilvánvalóan tudatos építészeti célt szolgált. Az a tény, hogy az épület föhomlokzatát röviddel elkészültét követően - a köztérre gyakorolt hatását tovább növelö módon - átépítették, szintén azt igazolja, hogy a felvázolt reprezentatív formaválasztás, tudatos építészeti célokat szolgált (6-7. ábra).

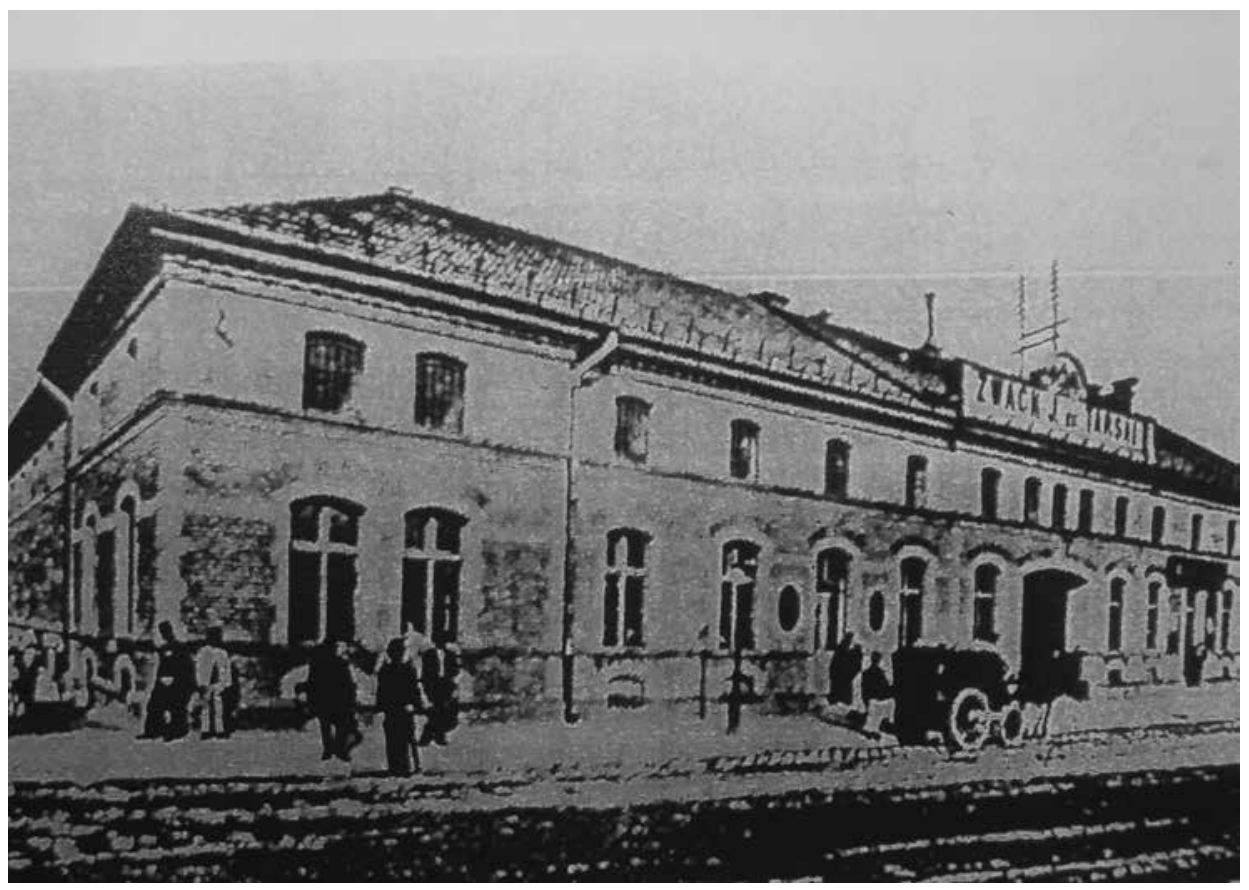

6. ábra. Zwack Likőrgyár. Soroksári úti homlokzat, 1894

(Forrás: Zwack Unicum Nyrt.) 


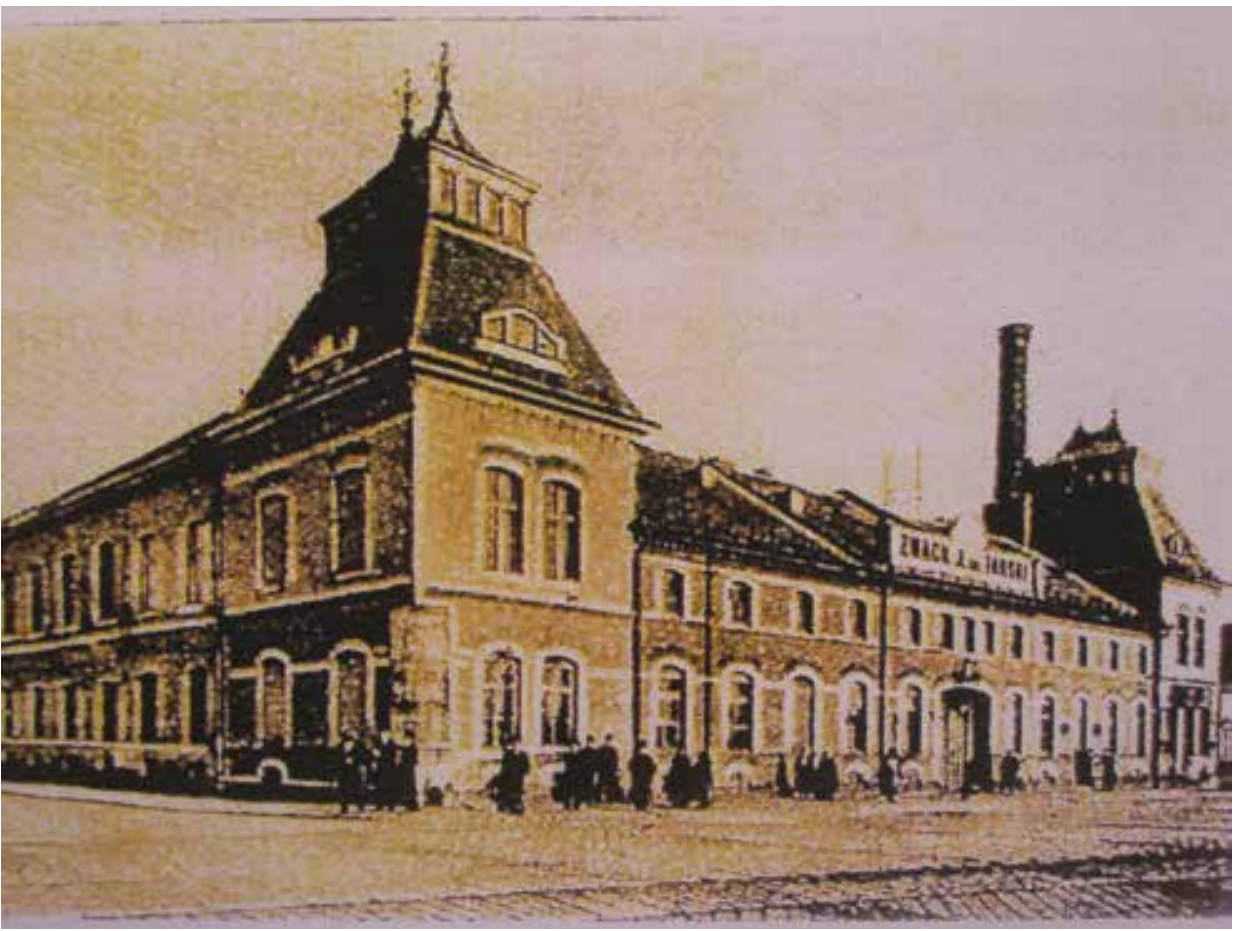

7. ábra. Zwack Likőrgyár. Soroksári úti homlokzat, 1905

(Forrás: Zwack Unicum Nyrt.)

Az épület oldalrizalitjait ennek megfelelően a 20. század első évtizedében saroktornyokkal emelték meg, melyek mind formai kialakításukkal, mind hangsúlyos technikai felépítményeikkel - szellőző lamelláikkal - skót whiskylepárló üzemekre emlékeztető alliterációként is értelmezhetők (Destillerie Ardbeg, Port Ellen, Islay, Argyll, 1815). ${ }^{28}$ A Zwack Likőrgyár esetén azonban ezeknek a jellegzetes építészeti elemeknek nem volt valódi müszaki rendeltetésük, így csupán esztétikai szempontokat szolgáltak. Az oldalrizalitok megmagasítása révén az épület szimmetriája még erőteljesebbé válik, míg maga az építmény várszerü bástyára emlékeztet. Az építészeti formanyelvben a bástya mint elem a hagyományosságot és a szolíd alapokon álló megbízhatóságot sugallja, ezért fontos szerepet játszik a vállalkozói önreprezentáció felértékelésében. ${ }^{29}$ 


\section{TÉRCENTRIKUS ÉPÍTÉSZETI KONCEPCIÓ A TÖRTÉNETI GYÁRÉPÜLETEK UTCAI TÉRHEZ VISZONYÍTOTT ELHELYEZÉSÉBEN}

Az Első Magyar Csavargyár tervezöi a gyárépület utcai térhez viszonyított elhelyezése tekintetében a Zwack Likőrgyártól eltérő térkoncepciót alkalmaztak. A Külső Váci úton 1894-ben létesített gyártóépület a telephelyet szegélyező út vonalához képest jelentős távolságra került elhelyezésre. Itt a gyár homlokzatának távolból érzékelhető hatásának tudatos tervezéséről beszélhetünk, ami a külső szemlélők (potenciális megrendelők és partnerek) vizuális érzékelésének befolyásolását szolgálta. Az üzem telephelyén az utca közvetlen szomszédságában kialakított átmeneti területen a vasárugyártással semmiféle funkcionális kapcsolatban nem álló előkertet hoztak létre. A külső térre gyakorolt hatás további elemének tekinthető az igényes építészeti kialakítású igazgatási épület is. A külső hatás fokozásának harmadik fontos eleme továbbá az utcához képest hátrébb elhelyezkedő gyártócsarnok főbejáratát díszítő két oldalsó torony. Ezek az építőelemek formaesztétikai és stilisztikai szempontból egyaránt szöges ellentétben álltak a modern gyártócsarnokkal és az ott elöállított innovatív termékekkel. Az építészet és a homlokzati kialakítás eszköztárával ily módon ,inszenált” külső tér tehát kizárólag a vállalat külvilágra gyakorolt hatását szolgálta (8. ábra).

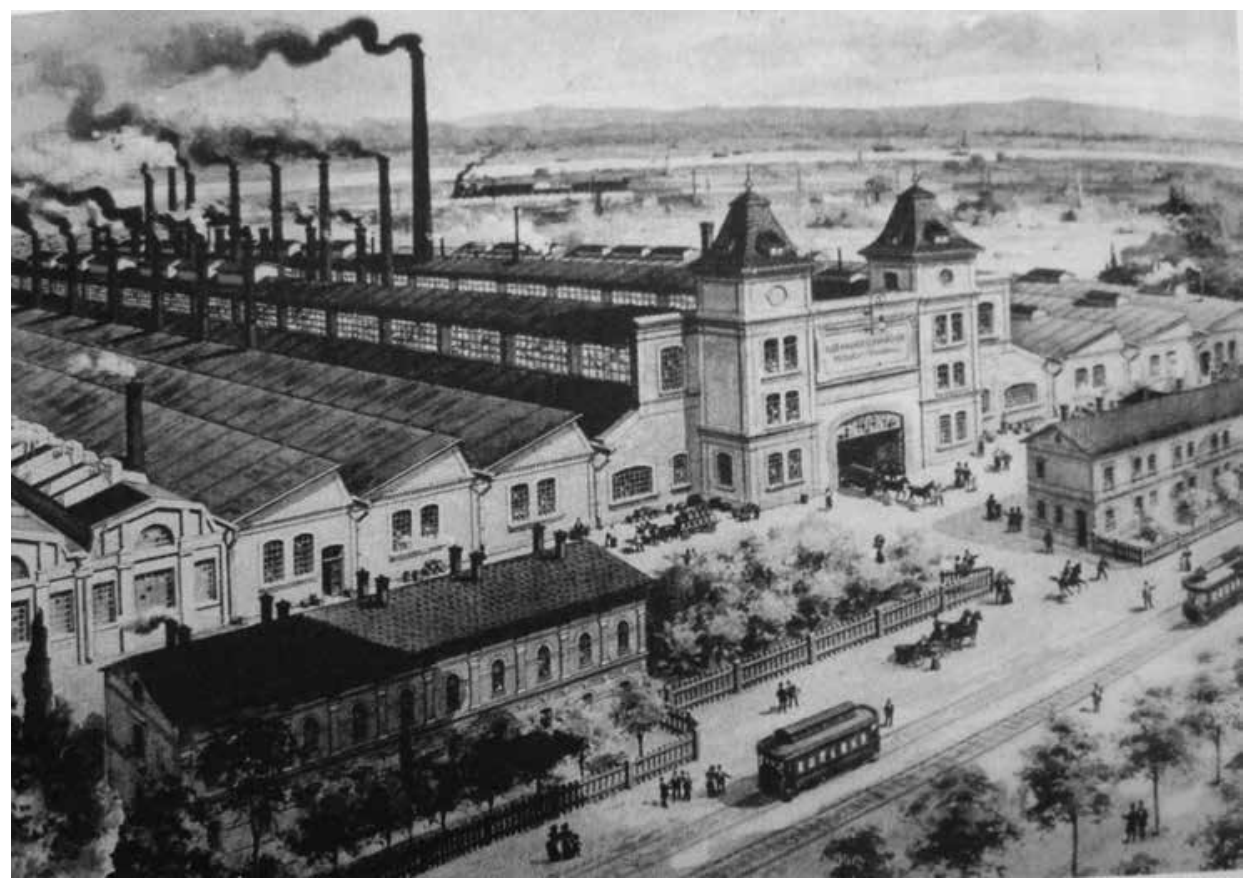

8. ábra. Első Magyar Csavargyár. Budapest. Külső Váci út, 1894 (Forrás: Bencze 2006) 


\section{A TÖRTÉNETI GYÁRHOMLOKZATOK MÜEMLÉKVÉDELMI SZEMPONTJAI}

A történeti gyárak homlokzatainak kialakítását a fejlődés kezdeti szakaszában az esztétikai szempontok dominálták, azonban később a trend a müszaki szükségszerüségek által determinált kialakítás irányába mozdult el. Ennek kiváltó okai közé sorolhatók az új gyártási technikák és a gépesítettség ezzel járó folyamatos növekedése, a központi energiaellátásra (a gőzenergiára) való áttérés és a modern üzemszervezési formák elterjedése. A fejlődés következtében egyre több müszaki felépítmény és müszaki elem gyakorolt hatást a homlokzati kialakításra, ami a homlokzatok egyre tárgyilagosabb (technicizáltabb) megközelítését eredményezte, mellyel párhuzamosan a (gyakran polgári) vállalkozó az üzem főhomlokzatát látványhomlokzatként terveztette meg. A homlokzat hagyományosságot és megbízhatóságot sugárzó, általában historizáló kialakítása révén egyrészt az üzemben gyártott termékek hagyományos jellegét volt hivatott hangsúlyozni, másrészt pedig a vállalkozó prezentációs igényét is szolgálta. Megfigyelhető, hogy a vállalatok gyakran eszközként alkalmazták az épületeik külső homlokzatát a hagyományok és a megbízhatóság szemantikus üzeneteinek a külvilág felé történő közvetítésére. Így az épületek a vállalat identitásának hordozóivá váltak. Napjainkban a történeti gyárépületek korábbi vállalati identitáshordozói szerepköre korunk társadalmi identitásának megszilárdításában juthat szerephez, amely szempont egyben a történeti gyárépületek homlokzatainak müemléki értékét is igazolhatja. A kulturális örökség védelméröl szóló 2001. évi LXIV. törvény a müemléki értéket az alábbiak szerint határozza meg: „müemléki érték: minden olyan építmény, kert, temető, temetkezési hely vagy sírjel, terület (illetve ezek maradványa), valamint azok rendeltetésszerúen összetartozó együttese, rendszere, amely hazánk múltja és a közösségi hovatartozás-tudat szempontjából kiemelkedő jelentőségü történeti, müvészeti, tudományos és müszaki emlék, alkotórészeivel, tartozékaival és berendezési tárgyaival együtt." Annak megítélésére, hogy mikor tulajdonítható egy ipari épület homlokzatának müemléki érték, és mely esetben lehet indokolt müemléki védelem alá helyezése, az alábbi definíció is kritériumként szolgálhat: A történeti gyártó létesítményeknek abban az esetben tulajdonitható müemléki érték, ha az ipari épület homlokzati funkciója túlmutat a puszta héj szerepén, és az alaprajzi kialakitással kapcsolatos elvek (tipizálás, sorozatképzés, központositás) esztétikai hatássá transzformálódása kiegészül az úgynevezett kontemplációs értékkel. Ezáltal az épület a kortárs megitélésen túlmutató jelentőséggel bir ${ }^{30}$ A történeti gyárépületek hídfunkciót tölthetnek be a múlt és a jelen között, vagyis hozzájárulnak a kulturális identifikáció fontos részét alkotó történeti kontinuitás megőrzéséhez. A müemlékvédelem feladata és értelme ennek megfelelően a kulturális identifikáció megőrzésében rejlik. Az egyes gyárépületek a város vagy városrész számára orientációs jelként (landmarkként) is szolgálhatnak, így nemcsak a földrajzi értelemben vett tájékozódást segítik, hanem történeti és szociális összefüggéseket

\footnotetext{
${ }^{30}$ Pilsitz 2012b.
} 
hordozva aktív társadalmi szerepet is betölthetnek. Ennek első lépéseként tudatformálásra és a vizuális érzékelés fejlesztésére van szükség az ipari építészettel kapcsolatban. A történeti gyártólétesítmények rendszerszemléletü kutatása és tudományos módszerekkel történő dokumentálása segít az ezzel kapcsolatos figyelem felkeltésében, és egyben gyakorlati úton is támogathatja a szükséges felfogásbeli fejlődést. Az ipari épületek homlokzata különösen alkalmas identitásteremtő üzenetek hordozására, hiszen az épületek az üzem bezárását követően is aktívan hatnak az őket körülvevő környező városi térre, ezért az ipari épületek homlokzatának önálló esztétikai érték tulajdonítható. ${ }^{31}$

\section{FELHASZNÁLT IRODALOM}

Bálint 1897

Balogh-Toldy-Gelléry 1885

Bandmann 1984

Bencze 2006

Borström 1989

Császár 1996

Dausz 1913

Dénes 1993

Distel 1929

Föhl 1981

Hassler-Kierdorf 2000

Hidvégi 2001

Horváth 2001

Kammerer 1985

Merten 1999

Nyárády 1962

${ }^{31}$ Wagenbreth 1995.
Bálint Zoltán: Az Ezredéves Kiállitás Architekturája. Schroll Antal és Tsa. Mükiadása, Bécs 1897. 29.

Balogh Vilmos - Toldy Ferenc - Gelléri Mór (szerk.): Kiállitási Kalauz. Budapest 1885.

Günther Bandmann: Ikonologie der Architektur. In: Architektur. Warnke, Berlin 1984. 19.

Bencze Géza: Váci út, a magyar gépipar föutcája. Országos Pedagógiai Könyvtár és Múzeum, Budapest 2006.

Jörg Borström: Industrie - Architektur - Fotographie. Bauwelt 35 (1989) 1614-1618.

Császár László: Új szerkezeti törekvések a millennium idején. Müemlékvédelem XI (1996) 2. 119-122.

Dausz Gyula: Köbánya ipara. Köbánya múltja és jelene. Első Köbányai Nyomda, Budapest 1913. 182-188.

Komárik Dénes: Feszl Frigyes (1821-1884). Akadémiai Kiadó, Budapest 1993.

Karl Distel: Ausstellungs- und Kongresshallen in Deutschland. Hamburg 1929.

Axel Föhl: Die Fotographie als Quelle der Industriearchäologie. In: Marburger Jahrbuch für Kunstwissenschaft. 20. Jg. Verlag des Kunstgeschichtl. Inst. d. Univ., Marburg 1981. 107-122.

Uta Hassler - Alexander Kierdorf: Denkmale des Industriezeitalters. Von der Geschichte des Umgangs mit Industriekultur. Verlag Ernst Wasmuth, Berlin-Tübingen 2000.

Hidvégi Violetta: Pavilonépítmények Pesten az egyesítést megelőző évtizedben. In: Prakfalvi 2001. 57-66.

B. Horváth Csilla: Az 1907-es pécsi Országos Kiállítás és Vásár. In: Prakfalvi 2001.

Hans Kammerer: Industriebau - eine kulturelle Aufgabe. Industriebau (1985) 1. 8-11.

Klaus Merten: Einführung in die Kommunikationswissenschaft. Band 1: Grundlagen der Kommunikationswissenschaft. LIT., Münster 1999. Nyárády Gábor: Az elsö Magyar Iparmü Kiállitása. Közgazdasági és Jogi Kiadó, Budapest 1962. 
Panofsky 1994

Pieper 1994

Pilsitz 2012a

Pilsitz 2012b

Pilsitz 2013

Plank 2001

Prakfalvi 2001

Taylor 1911

Váczi 2001

Wagenbreth 1995
Erwin Panofsky: Ikonographie und Ikonologie. Bildende Kunst als Zeichensystem. In: Ikonographie und Ikonologie. Vol. 1. Köln 1994. 207-225.

Jan Pieper: Die Maschine im Interieur. Ludwig Persius' Dampfmaschinenhaus im Babelsberger Park. Daidalos. Nr. 53. September 1994.

Martin Pilsitz: On the Industrial Urban Development of Pest in the 19th Century. Periodica Polytechnica Architecture 43 (2012) 1. 37-44. Martin Pilsitz: Múemlékvédelem az ipari építészetben. Épités - Épitészettudomány 40 (2012) 1-2.97-112.

Martin Pilsitz: Early Functionalism as a design principle of historical factory buildings in Budapest. Épités - Épitészettudomány 41 (2013) 3-4. 319-349.

Plank Ibolya Cs.: A fénykép, mint reprezantatív illustzráció a kiállitások történetében. In: Prakfalvi 2001. 123-130.

Fehérvári Zoltán - Hajdú Virág - Parakfalvi Endre (szerk.): Pavilon épitészet a 19-20. században a Magyar Építészeti Múzeum gyüjteményéböl. OMvH - Magyar Építészeti Múzeum - Pavilon Alapítvány, Budapest 2001.

Frederick Winslow Taylor: The Principles of Scientific Management. Harper \& Brothers, New York 1911.

Váczi Piroska: Az ipari épületek védelmének lehetőségei. Müemlékvédelem 45 (2001) 6. 379.

Ortfried Wagenbreth: Technikgeschichte und Industriearchitektur. Kritische Anmerkungen zur historischen Bearbeitung der Industriearchitektur. Technikgeschichte 62 (1995) 2. 138-139.

\section{INTERNETES FORRÁSOK}

Ardbeg 2015

Buechersammler 2015

Julius Maggie 2015

Packard 2011

Salviatmosaics 2015 www.ardbeg.com (Utolsó megtekintés: 2015. 09. 17.)

www.buechersammler.de (Utolsó megtekintés: 2015. 09. 14.)

www.Julius.Maggie.com (Utolsó megtekintés: 2015. 09. 12.)

www.packardfactorydetroit.com (Utolsó megtekintés: 2011. 05. 10.)

www.salviatmosaics.blogspot.hu (Utolsó megtekintés: 2015. 10. 20.)

\section{THE FACADES OF HISTORICAL FACTORY BUILDINGS IN BUDAPEST}

\section{Summary}

In the case of historical factory buildings the layout and the arrangement of the buildings were clearly based on functionality, but regarding the design of the facades there are a large number of theories and interpretations. In the following article examples from Budapest are used to show that in addition to the technical requirements, such factors as the specific place of construction, the holding of commercial exhibitions, and the need for representation also influenced the exterior design of historical factory buildings. In this context, an analysis of the facade of the Dreher Brewery (1860) serves to contribute to research on the work of Frigyes Feszl. What influence did the emergence of commercial exhibitions in 
the $19^{\text {th }}$ century in Budapest exert on the design of factory facades? Finally, the interaction between a historic industrial facade and the public space is shown by way of the construction chronology of the Zwack Liqueur Factory. By clarifying which conditions are required today for a facade to be listed as a historic monument, the topicality of the subject matter is demonstrated.

Keywords: historical industrial architecture, Zwack Liqueur Factory, Frigyes Feszl, Dreher Brewery, First Hungarian Screw Company, listed historic monument, industrial heritage in Budapest

\section{BEMERKUNGEN ZUR FASSADENGESTALTUNG HISTORISCHER FABRIKFASSADEN IN BUDAPEST}

\section{Zusammenfassung}

Während bei historischen Fabrikgebäuden die Planung des Grundrisses und die Anordnung der Gebäude auf dem Betriebsgelände aus der Zweckmäßigkeit heraus entstanden sind, gibt es bezüglich der Gestaltungsprinzipien und Deutung der Fassaden dieses Bautyps eine große Anzahl von Theorien und Interpretationen. Im folgenden Artikel soll an Beispielen Budapester Fabriken gezeigt werden, dass über technische Notwendigkeiten hinaus auch Faktoren wie die Bezugnahme auf den konkreten Standort, aber auch die aufkommenden Gewerbeausstellungen und das Bedürfnis nach Repräsentation Einfluss auf die Aussengestaltung historischer Fabrikgebäude genommen haben. In diesem Zusammenhang wird mit einer Analyse der Fassade der Brauerei Dreher (1865) ein Beitrag zur Forschung über das Werk des Budapester Architekten Frigyes Feszl geleistet. Welchen Einfluss die im 19. Jh. aufkommenden Gewerbeaustellungen in Budapest auf die Gestaltung von Fabrikfassaden genommen haben, ist ein weiterer Schwerpunkt der Untersuchung. Schließlich wird an der Bauchronologie der Likörfabrik Zwack die Wechselwirkung zwischen einer historischen Industriefassade und dem öffentlichem Raum aufgezeigt. Mit der Klärung der Frage, unter welchen Voraussetzungen heute eine Fassade dieses Bautyps ein Denkmal sein könnte, wird ein aktueller Bezug zum Thema hergestellt.

Schlüsselwörter: Industriearchitektur in Budapest, Likörfabrik Zwack, Frigyes Feszl, Brauerei Dreher, Denkmalschutz von Industriebauten in Budapest 